\title{
Selection of watermelon genotypes for resistance to bacterial fruit blotch
}

\author{
Francisco C. Q. Carvalho - Liliana A. Santos • \\ Rita C. S. Dias • Rosa L. R. Mariano • \\ Elineide B. Souza
}

Received: 20 April 2012/ Accepted: 12 July 2012

(C) Springer Science+Business Media B.V. 2012

\begin{abstract}
Bacterial fruit blotch, caused by Acidovorax citrulli, is a serious threat to the watermelon crop in Brazil. To date, there are no disease-resistant varieties, thus requiring research seeking sources of resistance. To select genotypes with potential use in the management of fruit blotch, the resistance level of watermelon genotypes belonging to the Cucurbits Germplasm Active Bank for the Brazilian Northeast (Banco Ativo de Germoplasma de Cucurbitáceas para o Nordeste Brasileiro-BAG) of Embrapa Semiárido was evaluated at different plant developmental stages: seeds (74 genotypes), seedlings and plants before flowering (29 genotypes) as well as plants during flowering and fruiting (seven genotypes). The genotypes were evaluated for the incidence or severity of the disease, which was estimated with the aid of descriptive scales. Additionally, A. citrulli transmission was determined in seeds derived from symptomatic and asymptomatic fruits. No watermelon genotype was immune to fruit blotch, and the majority
\end{abstract}

F. C. Q. Carvalho - L. A. Santos · R. L. R. Mariano ·

E. B. Souza $(\square)$

Phytobacteriology Laboratory, Department of Agronomy, Universidade Federal Rural de Pernambuco, Av. Dom

Manoel de Medeiros, S/N, Dois Irmãos, 52171-900

Recife, Pernambuco, Brasil

e-mail: elineidebs@yahoo.com.br

R. C. S. Dias

Embrapa Semiárido, BR 428, Km 152, Zona Rural,

56302-970 Petrolina, Pernambuco, Brasil showed variations in resistance responses. However, the genotypes BGCIA 979, BGCIA 34 and Sugar Baby showed high levels of resistance at most stages of plant development, thereby suggesting that these genotypes possess fruit blotch resistance genes that could be used in breeding programs. Seeds from symptomatic and asymptomatic fruits of the seven tested genotypes showed transmission rates of A. citrulli up to $35.3 \%$ and $8.7 \%$, respectively. These results confirm that asymptomatic fruits can harbor contaminated seeds that are responsible for the transmission of the bacteria.

Keywords Acidovorax citrulli $\cdot$ Citrullus lanatus . Genetic resistance $\cdot$ Pre-breeding $\cdot$ Seed transmission

\section{Introduction}

Watermelon (Citrullus lanatus) has emerged as an important agribusiness product in the Southeast and Northeast regions of Brazil (Agrianual 2011), which was ranked fourth among the major watermelon producing countries in 2010 (FAO 2010).

Bacterial fruit blotch, caused by Acidovorax citr$u l l i$, is a destructive disease that has been responsible for significant economic losses in watermelon, especially in the USA (Hopkins et al. 1993). In Brazil, although it is more relevant to the cultivation of melon, fruit blotch has been detected in watermelon crops in 
the states of Minas Gerais (Macagnan et al. 2003), Roraima (Halfeld-Vieira and Nechet 2007), Pernambuco, Rio Grande do Norte and Rio Grande do Sul, and has caused concern among producers and researchers. Epidemics of fruit blotch in watermelon have been attributed to the planting of contaminated seeds, thereby resulting in significant economic losses due to fruit sale restrictions. Bacterial fruit blotch represents a potential risk to watermelon crop production in Brazil because isolates of A. citrulli from melon are pathogenic to watermelon (Oliveira et al. 2007; Walcott et al. 2004). Furthermore, crops of these two cucurbits are often found in the same area, and the bacterium survives in volunteer seedlings and various alternative hosts found in cultivation areas (Nascimento et al. 2004; Oliveira et al. 2003; Robbs et al. 1991).

A. citrulli can affect different organs in watermelon at different developmental stages. However, the most common and readily diagnosed symptoms occur in fruits, where small water-soaked spots with irregular edges measuring less than $1 \mathrm{~cm}$ in diameter (Latin and Hopkins 1995) expand and become necrotic. Subsequently, the bacterium colonizes the fruit pulp, thereby contaminating the seed externally and internally, making it difficult to eradicate. Cracks are often visible, which accentuates fruit rot by the entry of secondary pathogens (Hopkins and Thompson 2002).

The various control measures recommended for fruit blotch, including the physical and chemical treatment of seeds (Hopkins et al. 2003; Moraes et al. 2002; Rane and Latin 1990; Silva Neto et al. 2003; Sowell and Schaad 1979) and chemical treatment in the field (Hopkins 1991; Latin and Hopkins 1995), have had limited effectiveness. Thus, other measures are necessary to reduce the damage caused by A. citrulli, and fruit resistance is considered to be the optimal control mechanism (Hopkins and Thompson 2002). However, fruit blotch resistant varieties of cucurbits have not been obtained to date.

Several selections for fruit blotch resistance have been performed with different accessions and varieties. However, the results have varied mainly due to differences in experimental conditions (Hopkins and Thompson 2002) and the high variability of the isolates that have been used (Hopkins 1993). Sowell and Schaad (1979) were the first to assess the watermelon genotypes PI 295843 and PI 299378 as potential sources of fruit blotch resistance, although this resistance has not been subsequently confirmed in inoculated seedlings and fruits (Hopkins et al. 1993). In 2002, a total of 1,344 Citrullus spp. and Praecitrullus fistulosus accessions were tested under winter and summer conditions in greenhouses and in the field, and PI 482279 and PI 494817 were found to have the lowest incidence of the disease on watermelon leaves in the field and were considered to be the best sources of fruit blotch resistance (Hopkins and Thompson 2002).

In Brazil, studies on selection for fruit blotch resistant watermelon have not been reported. In melon, Buso et al. (2004) evaluated 76 accessions from the Melon Germplasm Active Bank of Embrapa Horticultural (Banco Ativo de Germoplasma de Melão da Embrapa Hortaliças) and found five genotypes with significant levels of disease resistance.

Due to the socioeconomic importance of watermelon in Northeastern Brazil, the potential threat of fruit blotch for this crop as well as the lack of effective control measures for this disease, the objective of this study was to select watermelon genotypes with resistance to fruit blotch at different stages of plant development (i.e., seeds, seedlings, and plants).

\section{Materials and methods}

\section{Obtaining the Acidovorax citrulli isolate}

The A. citrulli isolate used in this study was IBSBF1213 obtained from a watermelon fruit from Presidente Prudente (SP) via the Phytobacteria Culture Collection of the Biological Institute (Coleção de Culturas de Fitobactérias do Instituto Biológico) and identified (primers WFB1 and WFB2). This isolate was characterized in relation to other isolates obtained from melon and watermelon by Silva (2010) and according to the profile of substrate utilization (BIO$\mathrm{LOG}^{\circledR}$ ) and BOX-PCR belongs to the group I of Walcott (Walcott et al., 2004). The bacterium was cultured on nutrient yeast-extract dextrose agar (NYDA) medium (Pusey and Wilson 1984), and pathogenicity tests were performed on seedlings, plants, and fruits of watermelon cv. Charleston Gray (Araújo et al. 2005; Silveira et al. 2003; Somodi et al. 1991).

For use in the experiments, the isolate was cultivated on NYDA medium for $36-48 \mathrm{~h}$ at $25 \pm 2{ }^{\circ} \mathrm{C}$. 
Distilled water was then added to the Petri dish containing the bacterial growth, and the suspension concentration was adjusted using a spectrophotometer $\left(\right.$ Analyzer $^{\circledR}$ ) at $570 \mathrm{~nm}$ absorbance, where $\mathrm{A}_{570}=$ 0.25 was considered to be equivalent to $3.4 \times 10^{7}$ $\mathrm{CFU} / \mathrm{ml}$. At the time of inoculation, Tween $20(0.05 \%$ $\mathrm{v} / \mathrm{v}$ ) was added to the bacterial suspension.

\section{Watermelon genotypes}

This study evaluated 74 watermelon genotypes belonging to the Cucurbit Germplasm Active Bank for the Brazilian Northeast (Banco Ativo de Germoplasma de Cucurbitáceas para o Nordeste BrasileiroBAG) of Embrapa Semiárido, in Petrolina (PE), Brazil (Table 1). The genotypes were preserved at $10{ }^{\circ} \mathrm{C}$ and $40 \%$ relative humidity.
Seed inoculation

A total of 20 seeds from each of the 74 watermelon genotypes were immersed for $2 \mathrm{~h}$ under mild agitation in $20 \mathrm{ml}$ of A. citrulli suspension and placed to dry for $16 \mathrm{~h}$ at room temperature $\left(25 \pm 2{ }^{\circ} \mathrm{C}\right)$. After drying, the seeds were sown in polyethylene trays (JKS Industrial LTDA $^{\circledR}$ ) containing a soil:humus (1:1) mixture and maintained in a greenhouse. The average temperature and relative air humidity were $31.6^{\circ} \mathrm{C}$ and $64.6 \%$ and $28.1{ }^{\circ} \mathrm{C}$ and $51.2 \%$ for experiments 1 and 2, respectively. After emergence, the trays were covered with plastic (moist chamber) for $24 \mathrm{~h}$. The evaluation was performed 14 days after planting for the determination of disease severity, which was evaluated with the aid of a descriptive scale. The descriptive scale ranged from 0 to 5: 0 - seedlings
Table 1 Genotypes and origin of watermelon used in this study

1 All watermelon genotypes in this study belong to the Cucurbit Germplasm Active Bank for the Brazilian Northeast (Banco Ativo de Germoplasma de Cucurbitáceas para o Nordeste Brasileiro-BAG) of Embrapa Semiárido, in Petrolina (PE), Brazil

\begin{tabular}{|c|c|}
\hline Genotype $^{1}$ & Origin \\
\hline $\begin{array}{l}\text { Crimson Select, Sugar Baby, Crimson Sweet, } \\
\text { Pérola, Charleston Gray, Riviera, } \\
\text { BRS Opara, Mickelee, Hollar } \\
\text { Premium, Peacock and BRS Kuarah }\end{array}$ & Cultivars obtained from seed industries \\
\hline $\begin{array}{l}\text { BGCIA } 2 \text {, BGCIA } 8, \text { BGCIA } 12, \\
\text { BGCIA } 26 \text {, BGCIA } 28, \text { BGCIA } 30, \\
\text { BGCIA } 34 \text {, BGCIA } 36 \text {, BGCIA } 43 \text {, } \\
\text { BGCIA } 64 \text {, BGCIA } 115 \text { and BGCIA } 123\end{array}$ & $\begin{array}{l}\text { Landraces from municipalities } \\
\text { of Bahia state, Brazil }\end{array}$ \\
\hline BGCIA 951, BGCIA 973 and BGCIA 976 & $\begin{array}{l}\text { Landraces from municipalities } \\
\text { of Pernambuco state, Brazil }\end{array}$ \\
\hline $\begin{array}{l}\text { BGCIA } 806, \text { BGCIA } 807, \text { BGCIA } 809 \text {, } \\
\text { BGCIA } 811, \text { BGCIA } 812, \text { BGCIA } 814 \text {, } \\
\text { BGCIA } 815, \text { BGCIA } 817 \text {, BGCIA } 818 \text {, } \\
\text { BGCIA } 819, \text { BGCIA } 820 \text {, BGCIA } 821 \text {, } \\
\text { BGCIA } 822, \text { BGCIA } 823 \text {, BGCIA } 824 \text {, } \\
\text { BGCIA } 825, \text { BGCIA } 826, \text { BGCIA } 827 \text {, } \\
\text { BGCIA } 829, \text { BGCIA } 830, \text { BGCIA } 833 \text {, } \\
\text { BGCIA } 834, \text { BGCIA } 835, \text { BGCIA } 843 \text {, } \\
\text { BGCIA } 849 \text { and BGCIA } 856\end{array}$ & $\begin{array}{l}\text { Landraces from municipalities } \\
\text { of Bahia and Maranhão states, Brazil }\end{array}$ \\
\hline $\begin{array}{l}\text { BGCIA 40, BGCIA 219, BGCIA } 225 \text {, } \\
\text { BGCIA 226, BGCIA 227, BGCIA } 240 \text {, } \\
\text { BGCIA } 857 \text {, BGCIA 952, BGCIA 953, } \\
\text { BGCIA 954, BGCIA 955, BGCIA 957, } \\
\text { BGCIA 959, BGCIA 960, BGCIA 961, } \\
\text { BGCIA 962, BGCIA 963, BGCIA 964, } \\
\text { BGCIA 967, BGCIA 975, } \\
\text { BGCIA } 979 \text { and CPATSA } 08.2214 .001\end{array}$ & $\begin{array}{l}\text { Progenies from breeding programs } \\
\text { of Embrapa Semiárido, Pernambuco state, } \\
\text { Brazil }\end{array}$ \\
\hline
\end{tabular}


without symptoms; 1 -seedlings with lesions covering up to $50 \%$ of the margins of one or both cotyledonary leaves; 2 -seedlings with lesions covering up to $75 \%$ of the margins of both cotyledonary leaves, few lesions in the center of the blade and slight leaf deformation; 3-seedlings with lesions covering $100 \%$ of the margins of both cotyledonary leaves, many lesions in the center of the blade, severe leaf deformation and stunting; 4-seedlings with lesions covering $100 \%$ of the margins of both cotyledonary leaves, many lesions in the center of the blade progressing to the hypocotyl, total leaf deformation and stunting; and 5-total necrosis of the cotyledonary leaves and hypocotyl, damping-off and death (Araújo et al. 2005). The cultivar Charleston Gray was used as the standard of susceptibility (Hopkins and Thompson 2002). The experimental design was completely randomized with five replicates consisting of four seedlings each.

\section{Seedling inoculation}

In the seedling inoculation experiment, 29 watermelon genotypes selected during the seed inoculation experiment were used to represent different levels of fruit blotch resistance. Seedlings were cultivated for 14 days in $300 \mathrm{ml}$ pots containing a soil:humus (1:1) mixture; the cotyledon leaves were then sprayed with the pathogen suspension until runoff (Araújo et al. 2005). During the experiments, the mean temperature and relative air humidity were $29.6{ }^{\circ} \mathrm{C}$ and $62.5 \%$. The pots were covered with plastic for $24 \mathrm{~h}$ (pre- and post-inoculation moist chamber) and then maintained in a greenhouse. Disease severity was evaluated at 6 days after inoculation using a descriptive scale ranging from 0 to 5: 0-seedlings without symptoms; 1 -seedling with lesions covering $25 \%$ of one or both cotyledons, hypocotyls without symptoms; 2-seedlings with lesions covering $26-50 \%$ of one or both cotyledons, hypocotyls without symptoms; 3 -seedling with lesions covering 51-75\% of one or both cotyledons, hypocotyl without symptoms; 4-seedlings with lesions covering 76-100 \% of one or both cotyledons, hypocotyl without symptoms; and 5total necrosis of cotyledons, lesions or total necrosis of the hypocotyl, damping-off and death of seedlings (Araújo et al. 2005). The experimental design was completely randomized with five replicates consisting of four seedlings each.
Inoculation of plants before flowering

The same 29 genotypes used in the previous experiment were cultivated for 5 weeks in $500 \mathrm{ml}$ pots containing a soil:humus (1:1) mixture; the true leaves were then sprayed with the pathogen suspension until runoff (Silveira et al. 2003). During the experiments, the average temperature and relative air humidity were $27.7{ }^{\circ} \mathrm{C}$ and $67.6 \%$, respectively. The plants were placed in a pre- and post-inoculation humid chamber for $24 \mathrm{~h}$ and maintained in a greenhouse. Disease severity was evaluated at 10 days after inoculation using a descriptive scale adapted from Azevedo (1997) with scores ranging from 0 to 6 : 0 - no symptoms; 1 1-5\% infected foliar area; $2-6-12 \%$ infected foliar area; 3-13-37\% infected foliar area; 4-38-62\% infected foliar area; 5-63-87\% infected foliar area; and 6-88-100\% infected foliar area. The experimental design was completely randomized with five replicates consisting of four plants each, and two leaves per plant were assessed.

Inoculation of plants in flowering and fruiting stages

The experiment was conducted in a screenhouse (50\% luminosity) of the Bebedouro Experimental Field of Embrapa Semiárido (Campo Experimental de Bebedouro da Embrapa Semiárido), PE, with seven watermelon genotypes, out of which six (BGCIA 979, BGCIA 34, 'Peacock', BGCIA 849, BGCIA 28 and 'Sugar Baby') were selected among the most resistant genotypes, and one ('Charleston Gray') was selected from among the most susceptible group. Seeding was performed in polystyrene trays filled with a commercial vegetables substrate $\left(\right.$ Plantmax $\left.^{\circledR}\right)$. At 12 days after sowing, the seedlings were transplanted to pots filled with $5 \mathrm{~L}$ of a natural soil:manure (3:1) mixture and $30 \mathrm{~g}$ of 6-24-12 fertilizer. In the cover, $10 \mathrm{~g} \mathrm{~N}$ (calcium nitrate) and $8 \mathrm{~g} \mathrm{~K}$ (potassium sulfate) per plant were fractionally applied at 20,30, and 40 days after planting. The plants were tutored and drip irrigated. The average temperature and relative air humidity in the screenhouse were $34.3{ }^{\circ} \mathrm{C}$ and $46.3 \%$, respectively.

During the development of female flowers (7 weeks after planting), the plants (leaves and flowers) were inoculated using a backpack sprayer $\left(\right.$ Guarany ${ }^{\circledR}$ ) until run-off of the pathogen suspension. 
At 15 days after inoculation, disease severity was evaluated using a descriptive scale with scores ranging from 0 to 6: $0-0 \%$ of symptomatic leaves; $1-10 \%$ or less of symptomatic leaves; $2-11-25 \%$ of symptomatic leaves; 3-26-50 \% of symptomatic leaves; $4-51-75 \%$ of symptomatic leaves; 5-76-90\% of symptomatic leaves; and 6-greater than $90 \%$ of symptomatic leaves (Bahar et al. 2009). The experimental design was completely randomized with four replicates consisting of four plants each.

Plants in the initial stages of fruiting (8 weeks after planting) were reinoculated (fruits), and the fruits near the maturation were assessed for disease incidence.

\section{Seed transmission test}

Fruits with disease symptoms and asymptomatic fruits were collected from the seven genotypes tested in the previous experiment. The seeds were washed and placed to dry at room temperature $\left(25 \pm 2{ }^{\circ} \mathrm{C}\right)$ for 20 days, and 40 seeds from each fruit were sown in polyethylene trays containing a soil:humus (1:1) mixture. Emerging seedlings were subjected to a humid chamber for $24 \mathrm{~h}$ and evaluated for disease incidence at 14 days after planting.

\section{Statistical analysis}

All experiments were conducted twice. The data were subjected to an analysis of variance (ANOVA) as well as a means comparison test (Tukey) or clustering test (Scott-Knott) at $5 \%$ probability using the software STATISTIX $^{\circledR}$ (Version 9.0, Analytical Software, Tallahassee, USA) and SISVAR $^{\circledR}$ (Ferreira 1992), respectively. For experiments that did not meet ANOVA assumptions, a nonparametric Kruskal-Wallis test at $5 \%$ probability was performed using the program STATISTIX ${ }^{\circledR}$.

\section{Results}

Seed inoculation

The results of the two experiments for selection of 74 fruit blotch resistant watermelon genotypes by seed inoculation with $A$. citrulli differed significantly, and therefore, the data were analyzed separately.
The genotypes showed a significant variation $(\mathrm{P} \leq 0.05)$ in fruit blotch resistance in both experiments. The average severity values represented nearly all levels of disease in experiment 1 (varying from 1.2-4.8), whereas less severity was observed in experiment 2 (0.2-3.1) (Table 2).

Different levels of fruit blotch resistance were showed by the genotypes, and variations were observed between the two experiments. In experiment 1, the genotypes 'Crimson Select,' BGCIA 843, BGCIA 979, BGCIA 952 and BGCIA 8 were the most resistant to fruit blotch (group A); however, they only differed significantly from BGCIA 959 (group B). In experiment 2, with the exception of genotype BGCIA 952 (group A), these same genotypes showed a greater susceptibility to disease than the others (groups B and C).

\section{Seedling inoculation}

As observed in the seed inoculation experiment, the similarity of the results from the two experiments was not significant, and thus the data analysis was performed separately.

In both experiments, the mean disease severity ranged from 2.3-4.0 (Table 3). Based on a maximum average severity of 3.7, 11 genotypes (38\%) classified into groups $\mathrm{A}$ and $\mathrm{B}$ of experiment 1 and 17 genotypes (58\%) assigned to groups A, B, C, D, E and F of experiment 2 showed some potential for fruit blotch resistance compared to the others (Table 3 ). It was observed that the genotypes BGCIA 962, BGCIA 28, BGCIA 34, BGCIA 979, BGCIA 849, BGCIA 952, BGCIA 8, 'Peacock' and 'Sugar Baby' maintained the resistance patterns and were among the groups $\mathrm{A}$ and $\mathrm{B}$ of experiment 1 and $\mathrm{A}, \mathrm{B}, \mathrm{C}, \mathrm{D}, \mathrm{E}$ and $\mathrm{F}$ of experiment 2 . In contrast, certain genotypes showed variations, such as the BGCIA 812 and 'Pérola', with some extent of resistance in experiment 1 and a high susceptibility in experiment 2 . The genotypes BGCIA 2, BGCIA 40 and BGCIA 12 showed the opposite behavior. The cv. Charleston Gray, considered to be a standard of susceptibility, showed high disease severity in both experiments.

Inoculation of plants before flowering

The results of both experiments conducted to assess fruit blotch resistance in 29 watermelon genotypes 
Table 2 The evaluation of fruit blotch disease resistance in different watermelon genotypes based on Acidovorax citrulli seed inoculation

\begin{tabular}{|c|c|c|c|c|c|c|c|}
\hline \multicolumn{4}{|l|}{ Experiment 1} & \multicolumn{4}{|l|}{ Experiment 2} \\
\hline Genotype & Severity $^{1}$ & Genotype & $\overline{\text { Severity }}$ & Genotype & Severity $^{1}$ & Genotype & \\
\hline 'Crimson Select' & $1.2 \mathrm{a}^{2}$ & BGCIA 829 & $2.6 \mathrm{ab}$ & 'Sugar Baby' & $0.2 \mathrm{a}^{3}$ & BGCIA 979 & $1.4 \mathrm{~b}$ \\
\hline BGCIA 843 & $1.2 \mathrm{a}$ & BGCIA 823 & $2.6 \mathrm{ab}$ & BGCIA 64 & $0.3 \mathrm{a}$ & BGCIA 809 & $1.5 \mathrm{~b}$ \\
\hline BGCIA 979 & $1.2 \mathrm{a}$ & 08.2214 .001 & $2.6 \mathrm{ab}$ & BGCIA 34 & $0.5 \mathrm{a}$ & 'Hollar Premium' & $1.5 \mathrm{~b}$ \\
\hline BGCIA 952 & $1.4 \mathrm{a}$ & BGCIA 240 & $2.6 \mathrm{ab}$ & BGCIA 36 & $0.6 \mathrm{a}$ & BGCIA 824 & $1.5 \mathrm{~b}$ \\
\hline BGCIA 8 & $1.4 \mathrm{a}$ & BGCIA 827 & $2.6 \mathrm{ab}$ & BGCIA 849 & $0.6 \mathrm{a}$ & 'Crimson Sweet' & $1.6 \mathrm{~b}$ \\
\hline 'Charleston Gray' & $1.4 \mathrm{ab}$ & BGCIA 973 & $2.6 \mathrm{ab}$ & BGCIA 115 & $0.6 \mathrm{a}$ & BGCIA 963 & $1.6 \mathrm{c}$ \\
\hline BGCIA 115 & $1.4 \mathrm{ab}$ & BGCIA 856 & $2.6 \mathrm{ab}$ & BGCIA 976 & $0.7 \mathrm{a}$ & 'Charleston Gray' & $1.6 \mathrm{c}$ \\
\hline 'BRS Opara' & $1.4 \mathrm{ab}$ & BGCIA 834 & $2.6 \mathrm{ab}$ & BGCIA 123 & $0.8 \mathrm{a}$ & 08.2214 .001 & $1.6 \mathrm{c}$ \\
\hline BGCIA 28 & $1.4 \mathrm{ab}$ & BGCIA 964 & $2.6 \mathrm{ab}$ & BGCIA 952 & $0.8 \mathrm{a}$ & BGCIA 959 & $1.7 \mathrm{c}$ \\
\hline BGCIA 976 & $1.5 \mathrm{ab}$ & BGCIA 953 & $2.6 \mathrm{ab}$ & BGCIA 819 & $0.8 \mathrm{a}$ & BGCIA 30 & $1.7 \mathrm{c}$ \\
\hline BGCIA 12 & $1.5 \mathrm{ab}$ & BGCIA 951 & $2.6 \mathrm{ab}$ & BGCIA 43 & $0.8 \mathrm{a}$ & BGCIA 2 & $1.7 \mathrm{c}$ \\
\hline BGCIA 849 & $1.6 \mathrm{ab}$ & BGCIA 815 & $2.6 \mathrm{ab}$ & BGCIA 815 & $0.8 \mathrm{a}$ & BGCI 240 & $1.8 \mathrm{c}$ \\
\hline BGCIA 40 & $1.5 \mathrm{ab}$ & 'Mickelee' & $2.7 \mathrm{ab}$ & BGCIA 975 & $0.8 \mathrm{a}$ & BGCIA 219 & $1.8 \mathrm{c}$ \\
\hline BGCIA 812 & $1.6 \mathrm{ab}$ & BGCIA 123 & $2.7 \mathrm{ab}$ & BGCIA 40 & $0.8 \mathrm{a}$ & BGCIA 12 & $1.8 \mathrm{c}$ \\
\hline 'Crimson Sweet' & $1.6 \mathrm{ab}$ & BGCIA 957 & $2.7 \mathrm{ab}$ & BGCIA 951 & $0.9 \mathrm{a}$ & BGCIA 957 & $1.8 \mathrm{c}$ \\
\hline BGCIA 821 & $1.7 \mathrm{ab}$ & 'Sugar Baby' & $2.8 \mathrm{ab}$ & BGCIA 964 & $0.9 \mathrm{a}$ & BGCIA 953 & $1.8 \mathrm{c}$ \\
\hline 'Pérola' & $1.8 \mathrm{ab}$ & BGCIA 26 & $2.8 \mathrm{ab}$ & BGCIA 227 & $0.9 \mathrm{a}$ & BGCIA 843 & $1.8 \mathrm{c}$ \\
\hline BGCIA 227 & $1.9 \mathrm{ab}$ & BGCIA 975 & $2.8 \mathrm{ab}$ & BGCIA 812 & $1.0 \mathrm{a}$ & BGCIA 827 & $1.9 \mathrm{c}$ \\
\hline BGCIA 811 & $2.0 \mathrm{ab}$ & BGCIA 820 & $2.8 \mathrm{ab}$ & BGCIA 811 & $1.0 \mathrm{a}$ & BGCIA 954 & $1.9 \mathrm{c}$ \\
\hline 'Peacock' & $2.0 \mathrm{ab}$ & BGCIA 226 & $2.8 \mathrm{ab}$ & BGCIA 973 & $1.1 \mathrm{~b}$ & BGCIA 825 & $2.0 \mathrm{c}$ \\
\hline 'Hollar Premium' & $2.0 \mathrm{ab}$ & BGCIA 833 & $3.0 \mathrm{ab}$ & 'Crimson Select' & $1.1 \mathrm{~b}$ & BGCIA 834 & $2.0 \mathrm{c}$ \\
\hline BGCIA 2 & $2.0 \mathrm{ab}$ & BGCIA 954 & $3.0 \mathrm{ab}$ & BGCIA 817 & $1.1 \mathrm{~b}$ & BGCIA 823 & $2.0 \mathrm{c}$ \\
\hline 'Riviera' & $2.0 \mathrm{ab}$ & BGCIA 818 & $3.0 \mathrm{ab}$ & BGCIA 28 & $1.2 \mathrm{~b}$ & BGCIA 821 & $2.0 \mathrm{c}$ \\
\hline BGCIA 825 & $2.0 \mathrm{ab}$ & BGCIA 830 & $3.0 \mathrm{ab}$ & BGCIA 814 & $1.2 \mathrm{~b}$ & BGCIA 962 & $2.0 \mathrm{c}$ \\
\hline BGCIA 814 & $2.0 \mathrm{ab}$ & BGCIA 219 & $3.0 \mathrm{ab}$ & BGCIA 807 & $1.2 \mathrm{~b}$ & BGCIA 961 & $2.0 \mathrm{c}$ \\
\hline BGCIA 807 & $2.1 \mathrm{ab}$ & BGCIA 822 & $3.1 \mathrm{ab}$ & BGCIA 26 & $1.2 \mathrm{~b}$ & BGCIA 955 & $2.1 \mathrm{c}$ \\
\hline BGCIA 963 & $2.1 \mathrm{ab}$ & BGCIA 960 & $3.2 \mathrm{ab}$ & BGCIA 226 & $1.2 \mathrm{~b}$ & BGCIA 857 & $2.1 \mathrm{c}$ \\
\hline BGCIA 64 & $2.1 \mathrm{ab}$ & BGCIA 955 & $3.2 \mathrm{ab}$ & BGCIA 225 & $1.2 \mathrm{~b}$ & BGCIA 835 & $2.1 \mathrm{c}$ \\
\hline BGCIA 967 & $2.2 \mathrm{ab}$ & BGCIA 857 & $3.2 \mathrm{ab}$ & BGCIA 820 & $1.3 \mathrm{~b}$ & 'Pérola' & $2.2 \mathrm{c}$ \\
\hline BGCIA 36 & $2.2 \mathrm{ab}$ & BGCIA 819 & $3.3 \mathrm{ab}$ & 'Peacock' & $1.3 \mathrm{~b}$ & 'BRS Opara' & $2.4 \mathrm{~d}$ \\
\hline BGCIA 43 & $2.2 \mathrm{ab}$ & BGCIA 809 & $3.4 \mathrm{ab}$ & BGCIA 818 & $1.4 \mathrm{~b}$ & BGCIA 830 & $2.4 \mathrm{~d}$ \\
\hline BGCIA 34 & $2.2 \mathrm{ab}$ & BGCIA 835 & $3.4 \mathrm{ab}$ & BGCIA 806 & $1.4 \mathrm{~b}$ & BGCIA 856 & $2.6 \mathrm{~d}$ \\
\hline BGCIA 817 & $2.3 \mathrm{ab}$ & BGCIA 225 & $3.4 \mathrm{ab}$ & 'Riviera' & $1.4 \mathrm{~b}$ & BGCIA 833 & $2.7 \mathrm{~d}$ \\
\hline 'BRS Kuarah' & $2.4 \mathrm{ab}$ & BGCIA 30 & $3.4 \mathrm{ab}$ & BGCIA 967 & $1.4 \mathrm{~b}$ & BGCIA 829 & $2.7 \mathrm{~d}$ \\
\hline BGCIA 824 & $2.5 \mathrm{ab}$ & BGCIA 961 & $3.6 \mathrm{ab}$ & BGCIA 8 & $1.4 \mathrm{~b}$ & BGCIA 826 & $2.7 \mathrm{~d}$ \\
\hline BGCIA 806 & $2.6 \mathrm{ab}$ & BGCIA 962 & $4.0 \mathrm{ab}$ & BGCIA 960 & $1.4 \mathrm{~b}$ & 'BRS Kuarah' & $2.8 \mathrm{~d}$ \\
\hline BGCIA 826 & $2.6 \mathrm{ab}$ & BGCIA 959 & $4.8 \mathrm{~b}$ & 'Mickelee' & $1.4 \mathrm{~b}$ & BGCIA 822 & $3.1 \mathrm{~d}$ \\
\hline & & & & & C.V. $=$ & & \\
\hline
\end{tabular}

${ }^{1}$ Disease severity based on symptoms appearance on seedlings: 0 —-seedlings without symptoms; 1 - seedlings with marginal lesions on up to $50 \%$ of one or both cotyledons; 2 - seedlings with marginal lesions of up to $75 \%$ of both cotyledons, few lesions in the center of the blade and slight leaf deformation; 3-seedlings with marginal lesions in $100 \%$ of both cotyledons, many lesions in the center of the blade, pronounced leaf deformation and stunting; 4-seedlings with marginal lesions in $100 \%$ of both cotyledons, many lesions in the center of the blade progressing to the hypocotyl, total leaf deformation and stunting; and 5-total necrosis of the cotyledon leaves and hypocotyl, dampingoff and death (Araújo et al. 2005)

${ }^{2}$ Means in columns followed by the same letter do not significantly differ from each other according to the non-parametric Kruskal-Wallis analysis

${ }^{3}$ Means in columns followed by the same letter do not significantly differ $(\mathrm{P} \leq 0.05)$ from each other according to the Scott-Knott grouping test 
Table 3 The evaluation of fruit blotch disease resistance in different watermelon genotypes based on Acidovorax citrulli seedlings inoculation

\begin{tabular}{|c|c|c|c|c|c|c|c|}
\hline \multicolumn{4}{|l|}{ Experiment 1} & \multicolumn{4}{|l|}{ Experiment 2} \\
\hline Genotype & Severity $^{1}$ & Genotype & Severity & Genotype & Severity $^{1}$ & Genotype & Severity \\
\hline BGCIA 962 & $3.4 \mathrm{a}^{2}$ & 'Riviera' & $3.8 \mathrm{c}$ & BGCIA 979 & $2.3 \mathrm{a}^{2}$ & BGCIA 976 & $3.6 \mathrm{f}$ \\
\hline 'Peacock' & $3.4 \mathrm{a}$ & BGCIA 227 & $3.9 \mathrm{c}$ & BGCIA 34 & $2.4 \mathrm{a}$ & BGCIA 40 & $3.6 \mathrm{f}$ \\
\hline BGCIA 28 & $3.4 \mathrm{a}$ & BGCIA 843 & $3.9 \mathrm{c}$ & 'Sugar baby' & $2.6 \mathrm{~b}$ & BGCIA 811 & $3.8 \mathrm{~g}$ \\
\hline BGCIA 34 & $3.4 \mathrm{a}$ & 'BRS opara' & $3.9 \mathrm{c}$ & BGCIA 36 & $2.8 \mathrm{c}$ & 'BRS Opara' & $3.8 \mathrm{~g}$ \\
\hline BGCIA 979 & $3.6 \mathrm{~b}$ & BGCIA 976 & $3.9 \mathrm{c}$ & BGCIA 959 & $2.9 \mathrm{c}$ & 'Hollar Premium' & $3.8 \mathrm{~g}$ \\
\hline BGCIA 849 & $3.6 \mathrm{~b}$ & 'Charleston Gray' & $4.0 \mathrm{~d}$ & BGCIA 962 & $3.0 \mathrm{c}$ & 'Crimson Select' & $3.8 \mathrm{~g}$ \\
\hline BGCIA 812 & $3.6 \mathrm{~b}$ & 'Crimson Select' & $4.0 \mathrm{~d}$ & 'Peacock' & $3.0 \mathrm{~d}$ & 'Charleston Gray' & $3.9 \mathrm{~g}$ \\
\hline BGCIA 952 & $3.6 \mathrm{~b}$ & BGCIA 811 & $4.0 \mathrm{~d}$ & BGCIA 2 & $3.0 \mathrm{~d}$ & BGCIA 812 & $4.0 \mathrm{~h}$ \\
\hline 'Sugar Baby' & $3.6 \mathrm{~b}$ & BGCIA 959 & $4.0 \mathrm{~d}$ & BGCIA 952 & $3.0 \mathrm{~d}$ & 'Pérola' & $4.0 \mathrm{~h}$ \\
\hline BGCIA 8 & $3.7 \mathrm{~b}$ & 'Crimson Sweet' & $4.0 \mathrm{~d}$ & BGCIA 12 & $3.1 \mathrm{~d}$ & 'Crimson Sweet' & $4.0 \mathrm{~h}$ \\
\hline 'Pérola' & $3.7 \mathrm{~b}$ & 'Hollar Premium' & $4.0 \mathrm{~d}$ & BGCIA 28 & $3.1 \mathrm{~d}$ & BGCIA 115 & $4.0 \mathrm{~h}$ \\
\hline BGCIA 36 & $3.8 \mathrm{c}$ & BGCIA 12 & $4.0 \mathrm{~d}$ & BGCIA 849 & $3.2 \mathrm{~d}$ & BGCIA 64 & $4.0 \mathrm{~h}$ \\
\hline BGCIA 115 & $3.8 \mathrm{c}$ & BGCIA 40 & $4.0 \mathrm{~d}$ & BGCIA 821 & $3.4 \mathrm{e}$ & BGCIA 227 & $4.0 \mathrm{~h}$ \\
\hline BGCIA 64 & $3.8 \mathrm{c}$ & BGCIA 2 & $4.0 \mathrm{~d}$ & 'Riviera' & $3.4 \mathrm{e}$ & BGCIA 843 & $4.0 \mathrm{~h}$ \\
\hline \multirow[t]{2}{*}{ BGCIA 821} & \multicolumn{3}{|l|}{$3.8 \mathrm{c}$} & BGCIA 8 & \multicolumn{3}{|l|}{$3.4 \mathrm{e}$} \\
\hline & \multicolumn{3}{|c|}{ C.V. $=15.04 \%$} & & \multicolumn{3}{|c|}{ C.V. $=13.47 \%$} \\
\hline
\end{tabular}

${ }_{1}^{1}$ Disease severity based on symptoms appearance on seedlings: 0 —seedlings without symptoms; 1 - seedling with lesions covering $25 \%$ of one or both cotyledons, hypocotyls without symptoms; 2-seedlings with lesions covering 26-50\% of one or both cotyledons, hypocotyls without symptoms; 3 - seedling with lesions covering 51-75\% of one or both cotyledons, hypocotyl without symptoms; 4 -seedlings with lesions covering 76-100\% of one or both cotyledons, hypocotyl without symptoms; and 5-total necrosis of cotyledons, lesions or total necrosis of the hypocotyl, damping-off and death of seedlings (Araújo et al. 2005)

${ }^{2}$ Means in columns followed by the same letter do not significantly differ $(\mathrm{P} \leq 0.05)$ from each other according to the Scott-Knott grouping test

before flowering were similar and significant between each experiment, and the data were analyzed together. The genotypes were divided into seven groups with fruit blotch severity values ranging from 1.5 for BGCIA 979 to 4.3 for BGCIA 843 (Table 4). These same genotypes also represented the extremes of resistance and susceptibility during seedling inoculation (experiment 2) (Table 3). At this plant developmental stage, $69 \%$ of the genotypes were included in the groups with greater resistance (A, B, C, and D).

Inoculation of plants in the flowering and fruiting stages

The results of both experiments conducted to assess the resistance of seven watermelon genotypes at the flowering and fruiting stages were significant among themselves, and the data were analyzed together.

Flowering plants showed a relatively low disease severity with a maximum average of 2.1 (Table 5) on a scale from 1-6 based on the percentage of symptomatic leaves (Bahar et al. 2009). The two most resistant genotypes at this stage, 'Sugar Baby' and BGCIA 979, differed significantly $(\mathrm{P} \leq 0.05)$ from the four most susceptible genotypes, 'Peacock', BGCIA 34, BGCIA 28 and BGCIA 849, which did not differ among each other (Table 5). 'Sugar Baby' and BGCIA 979 were among the most resistant in the inoculation experiments as seedlings (Table 3) and as plants before flowering (Table 4). The cv. Charleston Gray significantly differed from the most resistant ('Sugar Baby') and most susceptible (BGCIA 849) genotypes, although the results did not differ from the other treatments.

Disease incidence in fruits ranged from 43.3-100\% among the genotypes. The three genotypes with the lowest disease incidence (BGCIA 979, 'Sugar Baby' and BGCIA 34) showed significant results $(\mathrm{P} \leq 0.05)$ when compared with the three genotypes with the highest incidence ('Peacock', 'Charleston Gray' and BGCIA 849). As observed at other developmental 
Table 4 The evaluation of fruit blotch disease resistance in different watermelon genotypes based on Acidovorax citrulli inoculation of plants before flowering

\begin{tabular}{llll}
\hline Genotype & Severity & Genotype & Severity \\
\hline BGCIA 979 & $1.5 \mathrm{a}^{2}$ & BGCIA 64 & $2.2 \mathrm{c}$ \\
BGCIA 34 & $1.8 \mathrm{~b}$ & BGCIA 8 & $2.2 \mathrm{c}$ \\
BGCIA 811 & $1.8 \mathrm{~b}$ & BGCIA 976 & $2.3 \mathrm{c}$ \\
'Peacock' & $1.8 \mathrm{~b}$ & BGCIA 40 & $2.3 \mathrm{c}$ \\
BGCIA 849 & $1.8 \mathrm{~b}$ & BGCIA 959 & $2.7 \mathrm{~d}$ \\
BGCIA 28 & $1.8 \mathrm{~b}$ & 'Hollar Premium' & $3.0 \mathrm{e}$ \\
BGCIA 952 & $1.8 \mathrm{~b}$ & 'Crimson Sweet' & $3.0 \mathrm{e}$ \\
'Sugar Baby' & $1.9 \mathrm{~b}$ & 'BRS Opara' & $3.0 \mathrm{e}$ \\
BGCIA 821 & $1.9 \mathrm{~b}$ & 'Crimson Select' & $3.0 \mathrm{e}$ \\
BGCIA 962 & $2.0 \mathrm{c}$ & BGCIA 812 & $3.0 \mathrm{e}$ \\
BGCIA 2 & $2.0 \mathrm{c}$ & 'Charleston Gray' & $3.1 \mathrm{e}$ \\
BGCIA 227 & $2.2 \mathrm{c}$ & 'Pérola' & $3.1 \mathrm{e}$ \\
BGCIA 36 & $2.2 \mathrm{c}$ & 'Riviera' & $3.5 \mathrm{f}$ \\
BGCIA 12 & $2.2 \mathrm{c}$ & BGCIA 843 & $4.2 \mathrm{~g}$ \\
BGCIA 115 & $2.2 \mathrm{c}$ & & \\
C.V. = 10.58 \% & &
\end{tabular}

${ }_{1}$ Disease severity based on percentage of infected foliar area: 0 -no symptoms; $1-1-5 \%$ infected foliar area; 2-6-12\% infected foliar area; 3-13-37\% infected foliar area; 4$38-62 \%$ infected foliar area; $5-63-87 \%$ infected foliar area; and 6-88-100\% infected foliar area (adapted from Azevedo 1997)

2 Means in columns followed by the same letter do not significantly differ $(\mathrm{P} \leq 0.05)$ from each other according to the Scott-Knott grouping test

stages of watermelon, the cultivars Sugar Baby and Charleston Gray were the most resistant and the most susceptible to fruit blotch, respectively (Table 5).

Seed transmission test

The symptomatic and asymptomatic fruits of all genotypes had contaminated seeds that germinated into seedlings with symptoms typical of fruit blotch. The disease incidence in symptomatic fruits ranged from $7.3 \%$ (BGCIA 34) to $35.3 \%$ ('Charleston Gray'), whereas values ranging from $3.3 \%$ ('Charleston Gray') to $8.7 \%$ ('Sugar Baby') were observed in asymptomatic fruits (Table 6).

\section{Discussion}

Bacterial fruit blotch is a disease that is responsible for high economic losses in melon crop production in
Table 5 The evaluation of fruit blotch resistance in different watermelon genotypes through Acidovorax citrulli inoculation of plants during flowering and fruiting

\begin{tabular}{|c|c|c|c|}
\hline \multicolumn{2}{|l|}{ Flowering } & \multicolumn{2}{|l|}{ Fruiting } \\
\hline Genotype & Severity $^{1}$ & Genotype & $\begin{array}{l}\text { Incidence } \\
(\%)^{2}\end{array}$ \\
\hline 'Sugar Baby’ & $0.5 \mathrm{a}^{3}$ & BGCIA 979 & $43.3 \mathrm{a}^{3}$ \\
\hline BGCIA 979 & $0.7 \mathrm{ab}$ & 'Sugar Baby’ & $53.1 \mathrm{ab}$ \\
\hline 'Charleston Gray' & $1.2 \mathrm{bc}$ & BGCIA 34 & $62.5 \mathrm{ab}$ \\
\hline 'Peacock' & $1.6 \mathrm{~cd}$ & BGCIA 28 & $74.0 \mathrm{bc}$ \\
\hline BGCIA 34 & $1.6 \mathrm{~cd}$ & 'Peacock' & $87.5 \mathrm{~cd}$ \\
\hline BGCIA 28 & $1.7 \mathrm{~cd}$ & 'Charleston Gray' & $93.8 \mathrm{~cd}$ \\
\hline BGCIA 849 & $2.1 \mathrm{~d}$ & BGCIA 849 & $100.0 \mathrm{~d}$ \\
\hline C.V. $=20.63 \%$ & & C.V. $=10.80 \%$ & \\
\hline
\end{tabular}

${ }^{1}$ Disease severity based on percentage of symptomatic leaves on plant: $0-0 \%$ of symptomatic leaves; $1-10 \%$ or less of symptomatic leaves; $2-11-25 \%$ of symptomatic leaves; $3-$ 26-50\% of symptomatic leaves; 4-51-75\% of symptomatic leaves; 5-76-90\% of symptomatic leaves; and 6-greater than $90 \%$ of symptomatic leaves (Bahar et al. 2009)

${ }^{2}$ Number of symptomatic fruits among inoculated fruits from each plant

${ }^{3}$ Means in columns followed by the same letter do not significantly differ $(\mathrm{P} \leq 0.05)$ from each other according to the Tukey test

Brazil (Sales Júnior and Menezes 2001) and is a major threat to watermelon. This challenge justifies the development of breeding programs aimed at producing disease-resistant watermelon varieties, thus making it necessary to conduct research to find resistance sources.

There are two genetically and physiologically distinct groups of A. citrulli (Walcott et al. 2000, 2004). Group I strains included ATCC type strain as well as strains recovered from nonwatermelon cucurbit hosts, did not utilize L-leucine, and were moderately aggressive on a range of cucurbit hosts. Group II strains were isolated mainly from watermelon, utilize L-leucine and were more aggressive on watermelon than on other hosts. Knowledge of the two A. citrulli groups may be valuable in screening for watermelon fruit blotch resistance (Walcott et al. 2000). In Brazil, Silva (2010) found that all 40 A. citrulli strains studied belonged to group I, confirming the result of Walcott et al. (2004) for four of these strains. Therefore, the use of strain IBSBF1213 fits the purpose of effectiveness of genotype resistance in Brazilian conditions. 
Table 6 Acidovorax citrulli transmission by watermelon seeds from fruits symptomatic and asymptomatic

\begin{tabular}{lll}
\hline Genotype & $\begin{array}{l}\text { Number of } \\
\text { symptomatic } \\
\text { fruits/seed } \\
\text { transmission }(\%)^{1}\end{array}$ & $\begin{array}{l}\text { Number of } \\
\text { asymptomatic } \\
\text { fruits/seed } \\
\text { transmission (\%) }\end{array}$ \\
\hline BGCIA 34 & $11 / 7.3$ & $5 / 5.0$ \\
BGCIA 979 & $10 / 10.7$ & $12 / 6.8$ \\
BGCIA 28 & $13 / 11.1$ & $6 / 5.8$ \\
BGCIA 849 & $14 / 14.7$ & - \\
'Sugar Baby' & $8 / 15.6$ & $8 / 8.7$ \\
'Peacock' & $10 / 17.4$ & $2 / 7.4$ \\
'Charleston Gray' & $11 / 35.3$ & $3 / 3.3$ \\
\hline
\end{tabular}

${ }_{1}^{1}$ Percentage of Acidovorax citrulli transmission assessed by the disease incidence in seedlings $(n=40$ seeds per fruit)

Cucurbits are susceptible to fruit blotch at various plant developmental stages, which is an obstacle in the selection for resistance (Bahar et al. 2009). The combination of results from experiments performed at different plant developmental stages will make the selection of fruit blotch resistance sources more reliable under conditions of natural disease occurrence.

The selection of resistance sources through seed inoculation is important because $A$. citrulli inhabits seeds and can survive for 12 months under laboratory conditions on watermelon seeds originating from infected fruit (Hopkins et al. 1996). Moreover, pathogen transmission by seeds is very efficient, ranging from 33-91 \% and 10-69 \% according to O'Brien and Martin (1999) and Oliveira et al. (2001), respectively. A. citrulli transmission rates ranging from $16.7-100 \%$ were obtained in seed lots containing a single seed contaminated with bacteria at various concentrations $\left(1 \times 10^{1}\right.$ to $\left.1 \times 10^{7} \mathrm{CFU} / \mathrm{ml}\right)$ (Dutta et al. 2011).

In the seed inoculation experiment, humidity and temperature in particular likely contributed to a greater severity of fruit blotch in experiment 1 (temperature $31.6{ }^{\circ} \mathrm{C}$ and relative air humidity of $64.6 \%$ ) relative to experiment 2 (temperature of $28.1{ }^{\circ} \mathrm{C}$ and relative humidity of $51.2 \%$ ) and may have contributed to the greater variation in the results of the experiments. For example, genotypes resistant to the disease in one experiment, such as 'Crimson Select', BGCIA 843, BGCIA 979 and BGCIA 8, were susceptible to the disease in another experiment. The influence of environmental factors has been reported as being responsible for the variation in the resistance response to fruit blotch.

Hopkins and Thompson (2002), working with 1,344 accessions of Citrullus and P. fistulosus species, found that some had lower levels of fruit blotch resistance under summer conditions, whereas others showed lower resistance under winter conditions. Bahar et al. (2009) observed that the amount of light can directly contribute to disease intensity. In the autumn season (i.e., mostly cloudy days), the genotypes showed higher levels of disease severity, whereas lower levels were observed in the spring (i.e., mostly sunny days).

When A. citrulli was inoculated on watermelon seedlings, there was a higher severity of fruit blotch for most genotypes, with averages ranging from 2.3-4.0 (Table 3), relative to seed inoculation with severity values ranging from $0.2-4.8$ (Table 2 ), considering that both experiments were evaluated with diagrammatic scales ranging from $1-5$. This high susceptibility to fruit blotch has also been reported in melon at the initial and final developmental stages, namely seedlings and fruits (Bahar et al. 2009). Although the genotypes BGCIA 962, BGCIA 28, BGCIA 34, BGCIA 979, BGCIA 849, BGCIA 952, BGCIA 8, 'Peacock' and 'Sugar Baby' behaved as the most resistant in both seedling inoculation experiments, certain genotypes exhibited performance variations (BGCIA 812, 'Pérola', BGCIA 2, BGCIA 40 and BGCIA 12). The variability in the genotype responses to fruit blotch is explainable because most are landraces of watermelon and are highly heterozygous. With regards to the commercial cultivars and breeding program progenies, these genotypes were not previously selected for resistance to A. citrulli. This variation to fruit blotch resistance was also detected by Hopkins et al. (1993) when testing the watermelon accessions PI 295843 and PI 299378 that were previously selected by Sowell and Schaad (1979) with fruit blotch resistance, which behaved as susceptible. As expected, the cv. Charleston Gray showed high susceptibility to fruit blotch. This behavior, also reported by Goth and Webb (1981) and Hopkins and Thompson (2002), was the main reason for choosing this genotype as the susceptibility standard. Fruit blotch susceptibility of cultivars based on Crimson Sweet (Hollar Premium and Crimson Select), BRS Opara and Pérola was also confirmed under the studied conditions. 
Resistance at the seedling stage is important because after transplanting to the field, the bacterium is transmitted to neighboring seedlings or plants through rain and irrigation splash, infested soils, insects, farm equipment, field workers (Wiebe et al. 2001) and aerosols (Hopkins et al. 1992). Fruit blotch resistance at the seedling stage is most frequently studied using the spraying method, which has the advantage of requiring little space and time and is easily performed in the greenhouse (Bahar et al. 2009; Goth and Webb 1981; Hopkins et al. 1993; Hopkins and Thompson 2002; Sowell and Schaad 1979; Walcott et al. 2003).

When plants were inoculated before flowering, there was a lower fruit blotch severity for most genotypes. The lower disease severity at this stage of watermelon development can be explained by the fact that adult plants are relatively resistant to fruit blotch, often with imperceptible symptoms (Bahar et al. 2009). This effect may encourage escapes, thereby selecting resistant plants as susceptible genotypes. Regardless, similarities were found between the results of this experiment (Table 4) and the seedling inoculation experiment (Table 3), where the genotypes BGCIA 28, BGCIA 34, BGCIA 979, BGCIA 849, 'Peacock' and 'Sugar Baby' were grouped among the most resistant genotypes.

The lower fruit blotch severity observed in the seven genotypes inoculated with $A$. citrulli during the flowering stage is likely related to the plant developmental stage, as discussed above for the experiment with plants before flowering. Furthermore, the development conditions of the experiment in the screenhouse were significantly different than in the other tests, with a higher average temperature $\left(34.3^{\circ} \mathrm{C}\right)$ and lower relative air humidity $(46.3 \%)$. In this assay, the most resistant genotypes BGCIA 979 and 'Sugar Baby' confirmed the relative resistances demonstrate by the experiments on seedlings and plants before flowering.

Fruit inoculation occurred after fertilization, a stage that is considered to be more susceptible to fruit blotch (Wiebe et al. 2001), which explains the high incidence of the disease found in most genotypes. The lower and higher fruit disease susceptibility results observed in cvs. Sugar Baby and Charleston Gray, respectively, were similar to those obtained by Hopkins et al. (1993), who attributed the resistance to a phenotypic skin color trait. According Hopkins et al. (1993), cultivars such as Charleston Gray, which have a light green skin tone, had a tendency toward higher susceptibility relative to Sugar Baby, which has a dark green skin tone. In addition to 'Sugar Baby', the genotypes BGCIA 979 and BGCIA 34 were among the most resistant to fruit blotch, as observed during other watermelon developmental stages.

Since the economic losses caused by the disease are mainly related to the fruits rendering them not marketable (Latin and Hopkins 1995), it is essential to conduct resistance studies at the fruiting developmental stage. Provided that apparently healthy plants can be sources of $A$. citrulli inoculum and can contribute to a subsequent infection of the fruit (Latin and Hopkins 1995), experiments using both plants and fruits are important, even if the results do not correlate (Bahar et al., 2009).

The seed transmission experiment confirmed that watermelon fruits, whether symptomatic or asymptomatic, can harbor contaminated seeds and be responsible for the transmission of A. citrulli; however, a lower transmission rate was observed in asymptomatic fruit (maximum transmission of $8.7 \%$ ). Flowers of watermelon inoculated with $A$. citrulli by depositing $10 \mu \mathrm{L}$ of suspension also developed asymptomatic fruits carrying contaminated seeds, which produced seedlings with typical fruit blotch symptoms (Walcott et al. 2003). Bahar et al. (2009) obtained similar results in melon and emphasized the difficulties encountered by seed producers in obtaining pathogen-free seeds, especially under conditions that are not conducive to the development of symptoms in the fruit.

Fruit blotch resistance levels varied for most of the tested genotypes. For example, cv. Peacock was initially resistant to seed inoculation and subsequently alternated between being resistant (seedlings) and susceptible (fruiting). The same was true for the genotype BGCIA 849 which showed resistance to inoculation on seed, seedling and plants before flowering, but was the most susceptible during flowering and fruiting. In melon accessions, the great variation in fruit blotch resistance response was explained by a high genetic variability (Bahar et al. 2009) due to segregation among plants of the same accession (Buso et al. 2004) and by the ability of A. citrulli to infected plant organs at different developmental stages (Bahar et al. 2009).

Of the 74 watermelon genotypes that were tested, none were immune to fruit blotch. In general, the 
disease resistance reaction varied according to different plant developmental stages as well as different experimental conditions. However, BGCIA 979, BGCIA 34 and 'Sugar Baby' showed high levels of resistance at most plant developmental stages, thereby suggesting that these genotypes are disease resistance sources that may be used in breeding programs. Because it is a crop that has already been improved, Sugar Baby has the advantage of having a lower allelic frequency of undesirable genes, thus allowing a possible cross between this and other cultivars without interfering with other desirable agronomic characteristics.

The main control measure against fruit blotch is the planting of healthy seeds, which follows the general exclusion principle (Latin and Hopkins 1995). However, immunization to obtain and/or to incorporate resistance sources in cultivars reinforces this control (Hopkins and Thompson 2002) because disease-resistant watermelon plants produce pathogen-free seeds, thereby preventing the main form of dissemination.

Acknowledgments We thank the National Council for Scientific and Technological Development (CNPq), for the scholarships awarded to Francisco C. Q. Carvalho, Rosa L. R. Mariano and Elineide B. Souza.

\section{References}

Agrianual (2011) Anuário da agricultura brasileira. Instituto FNP, São Paulo

Araújo DV, Mariano RLR, Michereff SJ (2005) Métodos de inoculação de Acidovorax avenae subsp. citrulli em melão. Summa Phytopathol 31:69-73

Azevedo LAS (1997) Manual de quantificação de doenças de plantas. Novartis, São Paulo

Bahar O, Kritzman G, Burdman S (2009) Bacterial fruit blotch of melon: screens for disease tolerance and role of seed transmission in pathogenicity. Eur $\mathrm{J}$ Plant Pathol 123:71-83

Buso GSC, Nass LL, Marques ASA, Lopes CA, Buso JA (2004) Avaliação de genótipos de melão, visando identificar fontes de resistência a Acidovorax avenae subsp. citrulli. http://www.infoteca.cnptia.embrapa.br/bitstream/doc/1863 68/1/cot116.pdf. Accessed 24 jan 2012

Dutta B, Scherm H, Gitaitis RD, Walcott RR (2011) Acidovorax citrulli seed inoculum load affects seedling transmission and spread of bacterial fruit blotch of watermelon under greenhouse conditions. Plant Dis 96:705-711

Faostat (2010) Food And Agriculture Organization Of The United Nations. http://www.fao.org. Accessed 05 feb 2012

Ferreira DF (1992) SISVAR (Sistema para análise de variância para dados balanceados). UFLA, Lavras
Goth RW, Webb RE (1981) Resistance of commercial watermelon (Citrullus lanatus) to Pseudomonas pseudoalcaligenes subsp. citrulli. Plant Dis 65:671-672

Halfeld-Vieira BA, Nechet KL (2007) Mancha-aquosa da melancia em Roraima. Fitopatol Bras 32:268

Hopkins DL (1991) Chemical control of bacterial fruit blotch of watermelon. Proc Fla State Hort Soc 104:270-272

Hopkins DL (1993) Field spread of bacterial fruit blotch of watermelon. Phytopathology 83:466

Hopkins DL, Thompson CM (2002) Evaluation of Citrullus sp. germ plasm for resistance to Acidovorax avenae subsp. citrulli. Plant Dis 86:61-64

Hopkins DL, Stall B, Kucharek T, Gay D, Gitaitis R, Cook WP, Keinath APB, Latin R (1992) Bacterial fruit blotch in watermelon.http://plantpath.ifas.ufl.edu/takextpub/Fact Sheets/sicp1.pdf. Accessed 24 feb 2012

Hopkins DL, Thompson CM, Elmstrom GW (1993) Resistance of watermelon seedlings and fruit to the fruit blotch bacterium. HortScience 28:122-123

Hopkins DL, Cucuzza JD, Watterson JC (1996) Wet seed treatments for the control of bacterial fruit blotch of watermelon. Plant Dis 80:529-532

Hopkins DL, Cucuzza JD, Watterson JC (2003) Wet seed treatment with peroxyacetic acid for the control of bacterial fruit blotch and other seedborne diseases of watermelon. Plant Dis 87:1495-1499

Latin R, Hopkins DL (1995) Bacterial fruit blotch of watermelon. The hypothetical exam question becomes reality. Plant Dis 79:761-765

Macagnan D, Romeiro RS, Mendonça HL, Barreto RW (2003) Mancha bacteriana da melancia: uma nova doença no estado de Minas Gerais. Summa Phytopathol 29:286287

Moraes ISF, Medeiros FHV, Mariano RLR, Viana IO (2002) Proteção de plantas de melão contra Acidovorax avenae subsp. citrulli mediada por Bacillus spp. Fitopatol Bras 27:65-66

Nascimento ARP, Mariano RLR, Silva EI (2004) Hospedeiros alternativos de Acidovorax avenae subsp. citrulli. Hortic Bras 22:345-349

O’brien RG, Martin AL (1999) Bacterial blotch of melons caused by strains of Acidovorax avenae subsp. citrulli. Aust J Exp Agric 39:479-485

Oliveira IS, Sales Júnior R, Mariano RLR (2001) Acidovorax avenae subsp. citrulli: método de isolamento e transmissão por sementes. Fitopatol Bras 26:302

Oliveira IS, Sales Júnior R, Mariano RLR (2003) Ocorrência da mancha-aquosa por Acidovorax avenae subsp. citrulli em melão-pepino no Brasil. Fitopatol Bras 28:682

Oliveira JC, Silveira EB, Mariano RLR, Cardoso E, Viana IO (2007) Caracterização de isolados de Acidovorax avenae subsp. citrulli. Fitopatol Bras 32:480-487

Pusey PL, Wilson CL (1984) Postharvest biological control of stone fruit brown rot by Bacillus subtilis. Plant Dis 68:753-756

Rane KK, Latin RX (1990) Investigation of bacterial fruit blotch of watermelon. Phytopathology 80:1070

Robbs CF, Rodrigues Neto J, Ramos RS, Sinigaglia C (1991) Mancha bacteriana da melancia no estado de São Paulo, causada por Pseudomonas pseudoalcaligenes subsp. citrulli. Fitopatol Bras 16:48 
Sales Júnior R, Menezes JB (2001) Mapeamento das doenças fúngicas, bacterianas e viróticas do cultivo do melão no Estado do RN. Technical report. Escola Superior de Agricultura de Mossoró, Mossoró

Silva KMM (2010) Análise da diversidade de isolados de Acidovorax citrulli. $\mathrm{PhD}$ Thesis, Universidade Federal Rural de Pernambuco, Recife

Silva Neto EB, Medeiros FHV, Mariano RLR, Silveira EB (2003) Controle químico da mancha-aquosa do melão pelo tratamento de sementes. Fitopatol Bras 28:340

Silveira EB, Michereff SJ, Mariano RLR (2003) Severidade da mancha-aquosa em meloeiro sob diferentes condições de molhamento foliar e concentração de inóculo de Acidovorax avenae subsp. citrulli. Fitopatol Bras 28:171-175

Somodi GC, Jones JB, Hopkins DL, Stall RE, Kucharek TA, Hodge NC, Watterson JC (1991) Occurrence of a bacterial watermelon fruit blotch in Florida. Plant Dis 75:1053-1056

Sowell G, Schaad NW (1979) Pseudomonas pseudoalcaligenes subsp. citrulli on watermelon: seed transmission and resistance of plant introductions. Plant Dis 63:437-441
Walcott RR, Langston DB Jr, Sanders FH, Gitaitis RD (2000) Investigating intraspecific variation of Acidovorax avenae subsp. citrulli using DNA fingerprinting and whole cell fatty acid analysis. Phytopathology 90:191-196

Walcott RR, Gitaitis RD, Castro AC (2003) Role of blossoms in watermelon seed infestation by Acidovorax avenae subsp. citrulli. Phytopathology 93:528-534

Walcott RR, Fessehaie A, Castro AC (2004) Differences in pathogenicity between two genetically distinct groups of Acidovorax avenae subsp. citrulli on cucurbit hosts. J Phytopathol 152:277-285

Wiebe WL, Hopkins DL, Walcott RR (2001) Bacterial Fruit Blotch-A commercial growers guide. http://www.envirolo gix.com/artman/uploads/BFBGrowerGuide.pdf. Accessed 05 jan 2012 